\title{
Triped Cucumber Beetle Acalymma vittatum F. (Insecta: Coleoptera: Chrysomelidae) ${ }^{1}$
}

\author{
Braden Evans and Justin Renkema²
}

\section{Introduction}

The striped cucumber beetle, Acalymma vittatum F. (Figure 1 ) is a serious agricultural pest of plants in the family Cucurbitaceae in eastern North America. Crops affected by larval and adult feeding include cucumber, Cucumis sativus L., cantaloupe, Cucumis melo L., pumpkin, Cucurbita pepo L., and other Cucurbita spp. (Dill and Kirby 2016). The striped cucumber beetle is a vector of the plant disease bacterial wilt (Eaton 2016). Though the striped cucumber beetle occurs throughout Florida, it is the least commonly reported among three chrysomelid species on cucurbit crops in the state. The spotted cucumber beetle, Diabrotica undecimpunctata howardi Barber, and banded cucumber beetle, Diabrotica balteata LeConte, are more common in Florida, causing damage symptoms that are similar to striped cucumber feeding damage (Webb 2010).

\section{Distribution}

The striped cucumber beetle is indigenous to North America, widespread in the east, from as far south as Mexico, and north into southern Canada (CABI 2018). Though the species has been reported in western states and provinces, the Rocky Mountains are considered the western limit of its range. It is replaced in the west by Acalymma trivittatum Mannerheim, the western striped cucumber beetle (Reilly 2003).

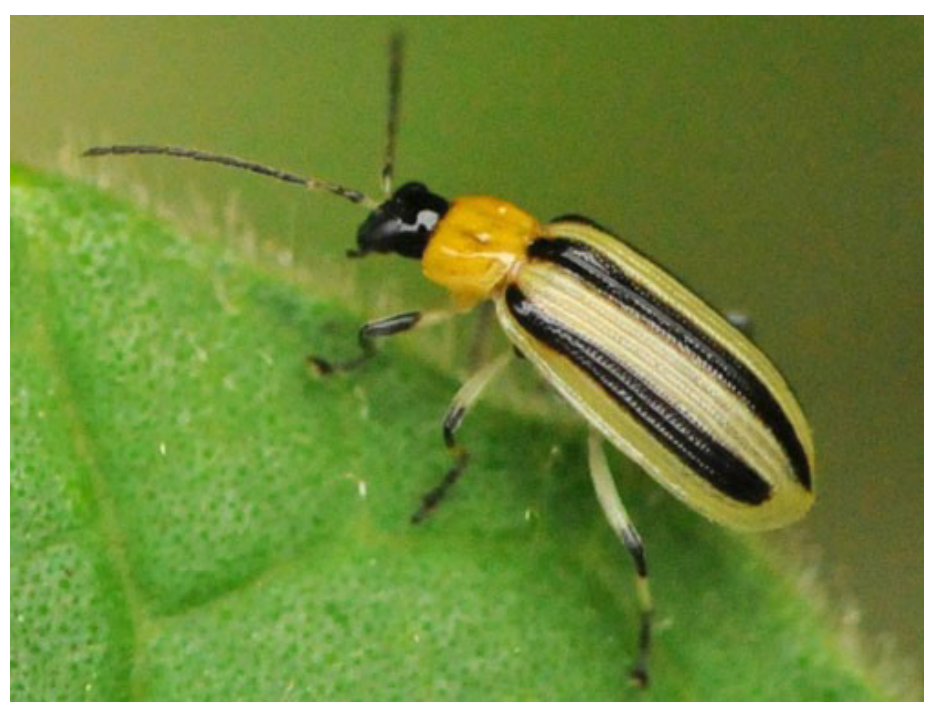

Figure 1. The striped cucumber beetle, Acalymma vittatum $\mathrm{F}$. Credits: John Capinera, UF/IFAS

\section{Description and Life Cycle}

Unmated adults of the striped cucumber beetle overwinter under organic debris in hedgerows and field margins surrounding plots of land that were cultivated with cucurbit crops. Adults emerge in the spring when soil temperatures reach $13^{\circ} \mathrm{C}\left(55^{\circ} \mathrm{F}\right)$ and feed on pollen and foliage of alternative host plants, such as willow, apple, hawthorn, goldenrod, and aster, when cucurbits are unavailable (Dill and Kirby 2016). When cucurbit seedlings are transplanted or emerge, adults move to these preferred hosts to feed and mate. Adults initially colonize field edges and spread throughout

1. This document is EENY-707, one of a series of the Department of Entomology and Nematology, UF/IFAS Extension. Original publication date May 2018. Visit the EDIS website at http://edis.ifas.ufl.edu. This document is also available on the Featured Creatures website at http://entomology.ifas.ufl.edu/ creatures.

2. Braden Evans and Justin Renkema; Department of Entomology and Nematology, UF/IFAS Extension, Gainesville, FL 32611.

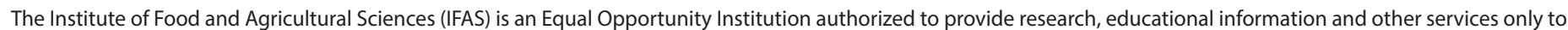

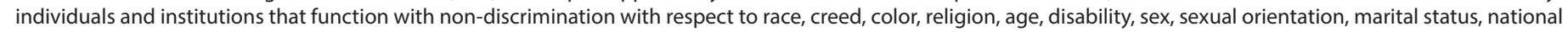
origin, political opinions or affiliations. For more information on obtaining other UF/IFAS Extension publications, contact your county's UF/IFAS Extension office. 
the crop over the course of the growing season. Striped cucumber beetle adults form large aggregations on individual plants in the spring to mate (Radin and Drummond 1994). Eggs are then laid at the base of plant stems, below the soil surface. Following the eclosion of eggs, larvae move down to the roots to feed, pupate in the soil, and subsequently emerge as the next generation of adults. Depending on latitude and climate, the striped cucumber beetle may complete one to three generations per year (Eaton 2016).
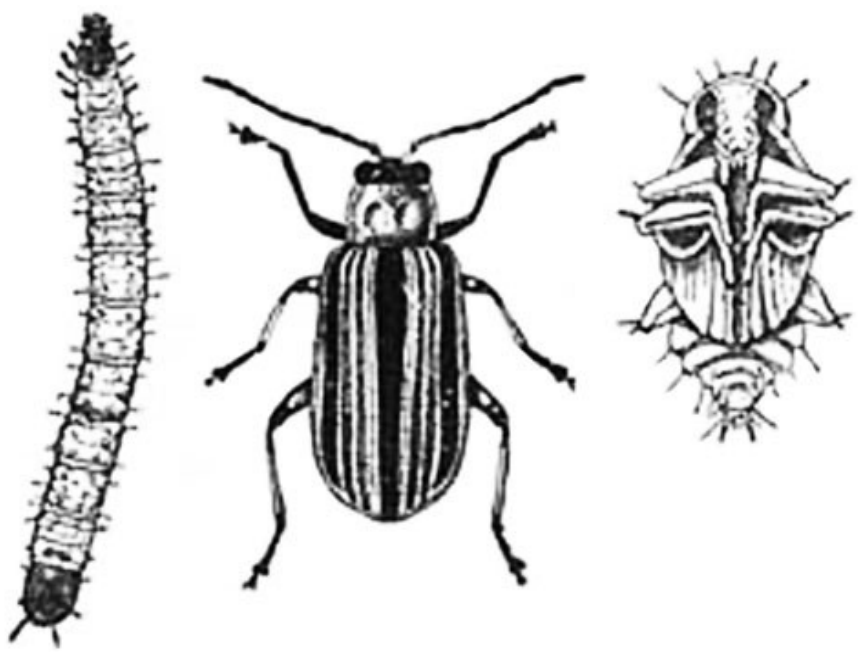

Figure 2. Larval, adult, and pupal stages of the striped cucumber beetle, Acalymma trivittatum F.

Credits: Eric Day, Department of Entomology, Virginia Tech

\section{Eggs}

Eggs are deposited in small clusters of up to four eggs (Ellers-Kirk and Fleischer 2006) about $5 \mathrm{~cm}$ into moist cracks in the soil within a $\sim 15 \mathrm{~cm}$ diameter around the base of the stem (Duval 1994). The oval-shaped eggs are yellow or orange, averaging $0.60 \mathrm{~mm}$ long $\mathrm{x} 0.36 \mathrm{~mm}$ wide, and are characterized by a textured surface (Houser and Balduf 1925; Isley 1927). A female may lay up to 4 eggs per day and up to 125 eggs in her lifetime, and egg incubation takes five to nine days (Legault 2007).

\section{Larvae}

First instars are $1.3 \mathrm{~mm}$ in length; they emerge from eggs and begin to feed on the roots and stems of cucurbits (Houser and Balduf 1925). Larvae are white, slender, and 'worm-like', with dark-brown head capsules (Figure 3). Three larval instars are completed in two to four weeks, and third instars can reach a length of $1 \mathrm{~cm}$ (Macintyre 2000; Legault 2007).

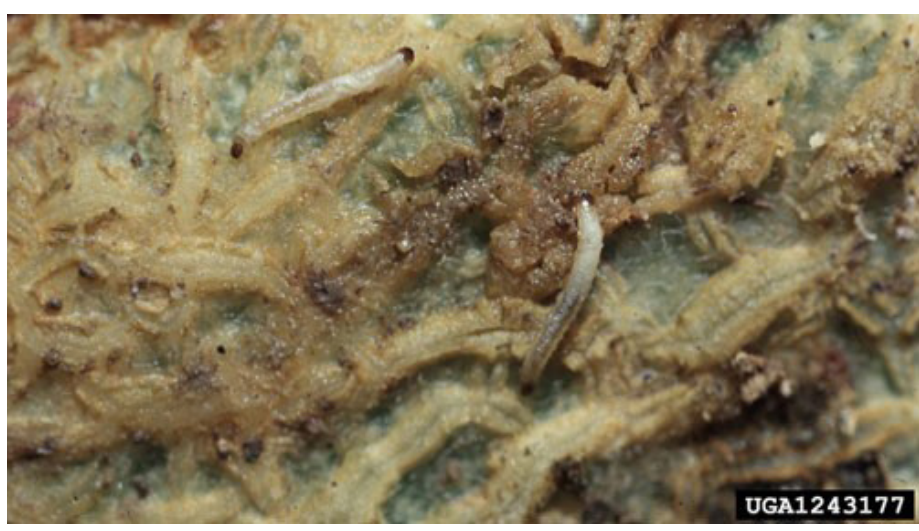

Figure 3. Larvae of the striped cucumber beetle, Acalymma vittatum F. are characterized by a white thorax and abdomen and a dark head capsule.

Credits: Whitney Cranshaw, Colorado State University, Bugwood.org

\section{Pupae}

The striped cucumber beetle pupates in the soil, near the base of its host plant. Pupae are white, eight to $10 \mathrm{~mm}$ in length, with a broad shape anteriorly and tapering to a narrow point at the distal end of the abdomen (Houser and Balduf 1925).

\section{Adults}

Striped cucumber beetles have a brown or black head, with a bright yellow prothorax and black abdomen. The elytra are yellow, with three longitudinal black stripes running along their entire length (Houser and Balduf 1925). Adults are approximately $5.25 \mathrm{~mm}$ long and $1.3 \mathrm{~mm}$ wide (Munroe and Smith 1980). An important distinction must be made between adults of the striped cucumber beetle and the western corn rootworm, Diabrotica virgifera LeConte, which may be confused in the field. Western corn root worm adults are longer $(\sim 6.3 \mathrm{~mm})$, with black and yellow markings that do not extend the entire length of the elytra (Hoffmann and Zitter 1994).

\section{Damage}

Adults feed on flowers, leaves and fruit, but focus their feeding on the undersides of developing fruit during warm periods (Hoffmann and Zitter 1994). Feeding on flowers and leaves may result in severe defoliation, whereas feeding on fruit produces scarring damage that directly reduces yield (Figures 4, 5, 6, and 7). The striped cucumber beetle shows a strong preference for plants in the family Cucurbitaceae, with gourds, squash, zucchini (all cultivars of Cucurbita pepo L.), and cucumbers, Cucumis sativus L., favored over pumpkins, Cucurbita pepo, muskmelon, $\mathrm{Cucu}$ mis melo L., butternut squash, Cucurbita moschata Duchesne, and watermelon, Citrullus lanatus Thunberg (Boucher 2003). 


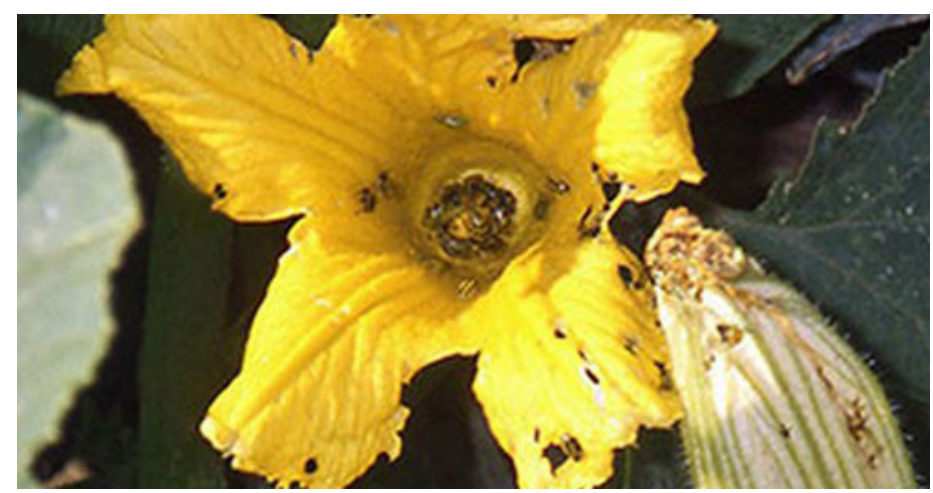

Figure 4. Feeding damage to flower blossoms caused by adult striped cucumber beetle, Acalymma vittatum $\mathrm{F}$.

Credits: E. C. Burkness, University of Minnesota

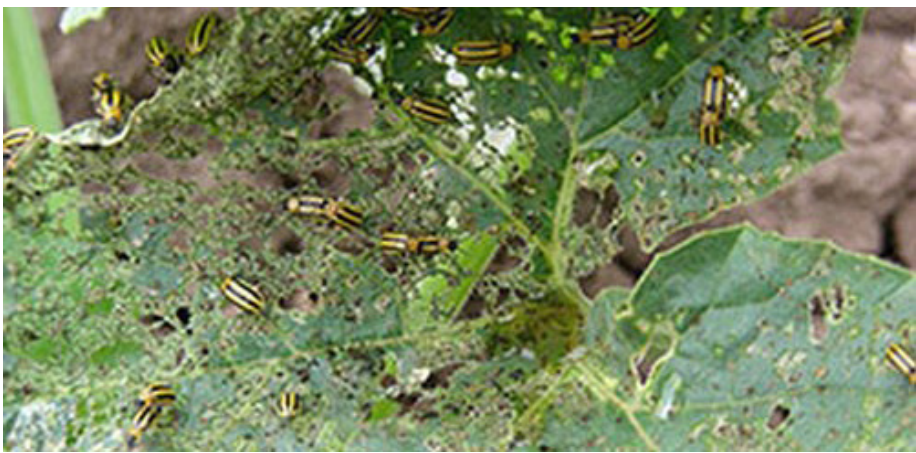

Figure 5. Feeding damage to foliage caused by adult striped cucumber beetle, Acalymma vittatum $\mathrm{F}$.

Credits: E. C. Burkness, University of Minnesota

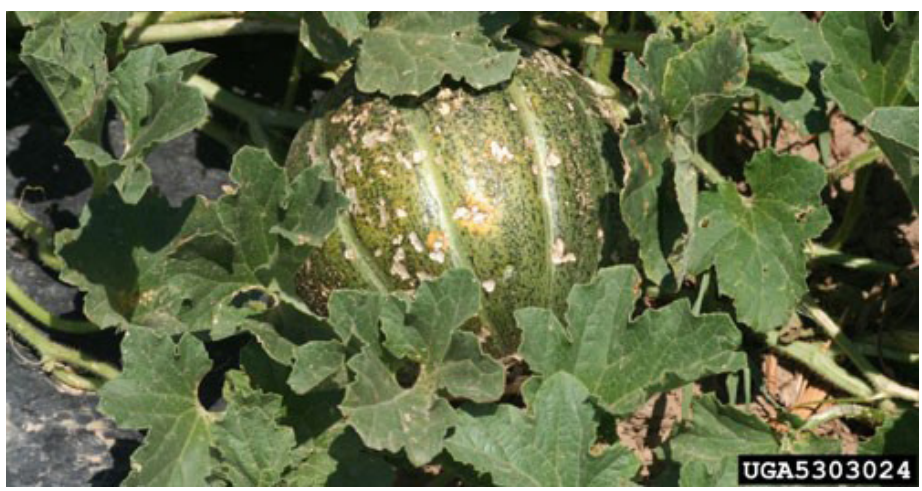

Figure 6. Feeding damage to fruit rinds, caused by adult striped cucumber beetle, Acalymma vittatum $\mathrm{F}$.

Credits: Whitney Cranshaw, Colorado State University, Bugwood.org

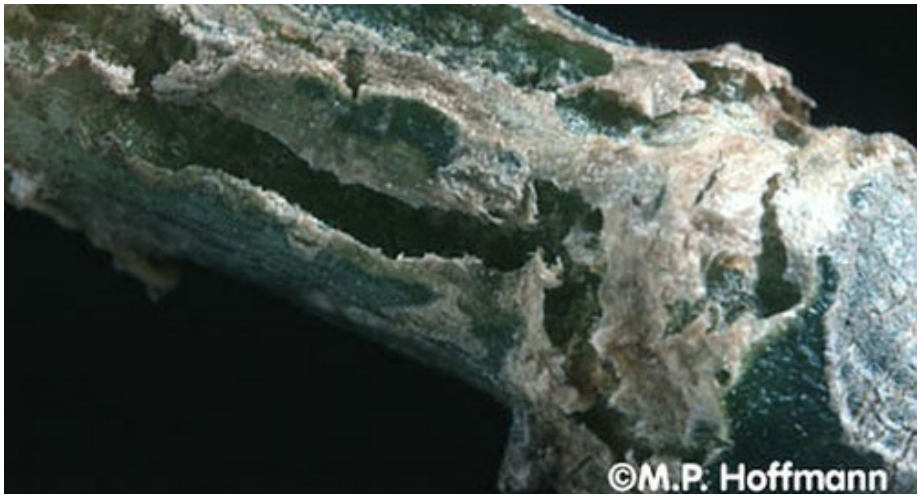

Figure 7. Scarring of a stem caused by tunneling of larvae of the striped cucumber beetle, Acalymma vittatum F. during feeding. Credits: M. P. Hoffmann, Cornell University
The cotyledons of seedlings and wilting plants are particularly attractive to striped cucumber beetle since they contain a high concentration of cucurbitacins, the metabolites produced by the plants in response to herbivorous attack. This is an example of coevolution between the striped cucumber beetle and cucurbits, whereby a repellent defense evolved by the host plant has been adopted as a feeding stimulant by the herbivorous beetle (Hoffmann and Zitter 1994). When feeding on cucurbits, adult male striped cucumber beetles produce an aggregation pheromone, which attracts more individuals into the area (Boucher 2003). Although adults can subsist on alternate host plants, mating and oviposition only occurs on cucurbits. Larvae feed exclusively on the roots and stems of cucurbits, but the resulting economic impact of the damage is not significant (Figures 8 and 9).

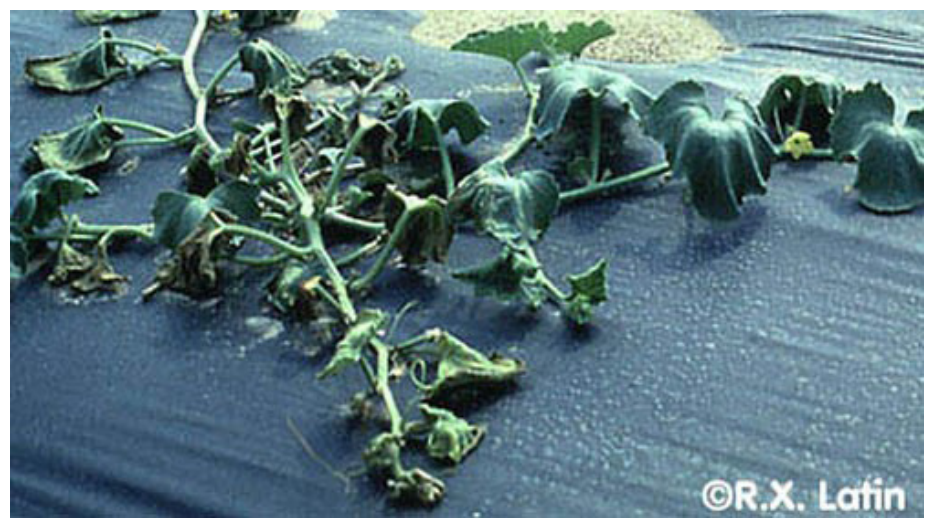

Figure 8. Wilted plants may indicate the presence of bacterial wilt disease, caused by the pathogen Erwinia tracheiphila, vectored by the striped cucumber beetle Acalymma vittatum $\mathrm{F}$.

Credits: R. X. Latin, Purdue University

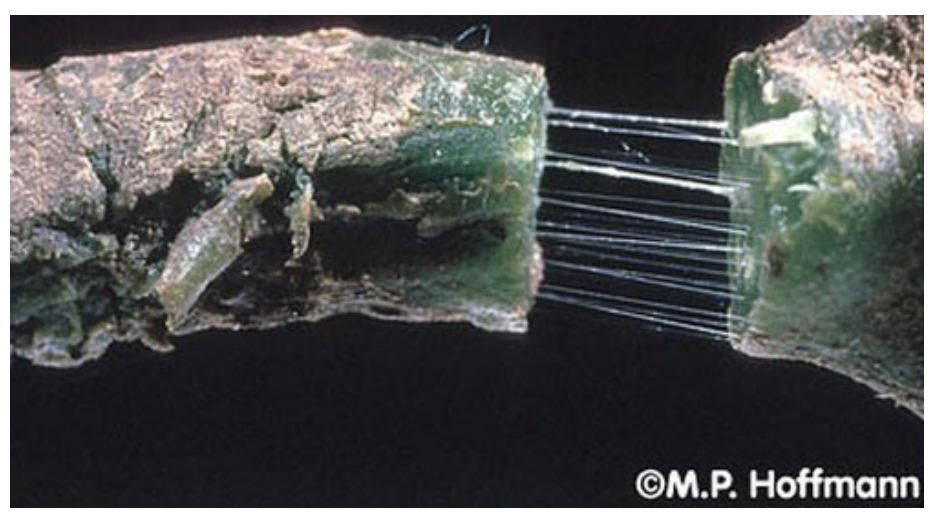

Figure 9. Stringy strands inside stems may indicate the presence of bacterial wilt disease, caused by the pathogen Erwinia tracheiphila, vectored by the striped cucumber beetle Acalymma vittatum $\mathrm{F}$. Credits: M. P. Hoffmann, Cornell University

In addition to direct feeding damage, the striped cucumber beetle (along with the spotted cucumber beetle) is the primary vector of bacterial wilt disease in cucurbits, caused by the pathogen Erwinia tracheiphila (Radin 1996). Erwinia tracheiphila can overwinter in the gut of 
the striped cucumber beetle, and a plant becomes infected when damaged foliage contacts beetle frass or infected body parts. Inside the plant, the bacteria multiply and block the vascular system, obstructing the flow of water and nutrients. Symptoms of the disease initially include wilted leaves which turn pale green, followed by wilting of the plant and eventual necrosis. Bacterial ooze, the white, stringy sap-like exudate that extends from the ends of cut symptomatic stems when placed in water, is a sign this pathogen is present (Jarvis 1994). The potential for yield losses from bacterial wilt are reported to be far more extensive than direct losses from striped cucumber beetle feeding damage. Along with bacterial wilt, the striped cucumber beetle may also transmit cucumber mosaic, cowpea mosaic, and pumpkin mosaic viruses (Legault 2007).

\section{Monitoring}

Monitoring for striped cucumber beetle is particularly important early in the season when seedlings are transplanted or begin to emerge, since early season infestations are typically the most damaging (Boucher 2003). Newly emergent cotyledons and plants in the 1st to 3rd true leaf stage are most susceptible to defoliation and bacterial wilt (Hahn 2005). In Florida, cucumber beetles are considered occasional pests and are most active in the morning and late afternoon (Webb 2010). Thresholds for the application of insecticides vary based on local striped cucumber beetle abundance and the prevalence of bacterial wilt in a region.

\section{Management}

Early treatment during peak adult activity for two to four weeks in the spring is important in striped cucumber beetle management, potentially reducing pest pressure for the remainder of the season (Boucher 2003; Bessin 2004).

\section{Biological Control}

Predators, pathogens, and parasitoids are important for reducing pest population outbreaks (Boucher 2003; Snyder 2015). Naturally-occurring invertebrate predators (i.e., harvestmen, ground beetles, rove beetles, spiders, and spider mites) and vertebrate predators (bats) have been reported to feed on the striped cucumber beetle in agroecosystems (Whitaker 1995; Snyder and Wise 2001; Williams and Wise 2003). Naturally-occurring populations of a parasitoid fly Celatoria setosa Coquillett (Diptera: Tachinidae) and wasp Centistes (Syrrhizus) diabroticae Gahan (Hymenoptera: Braconidae) have been reported to infect the striped cucumber beetle at rates of up to $43 \%$ and $54 \%$, respectively (Smyth and Hoffmann 2010). Disease-causing agents of insects, such as entomopathogenic nematodes and fungi, target soil-dwelling insect life stages. These organisms have potential for suppressing larval feeding on roots, but they are unlikely to affect the adult life stage. (Reed et al. 1986; Choo et al. 1996; Ellers-Kirk et al. 2000).

\section{Plant Resistant Varieties}

The compound cucurbitacin gives cucurbit plants a bitter taste and serves as a defense against generalist herbivores (Deheer and Tallamy 1991). The striped cucumber beetle, however, is a co-evolved specialist for which cucurbitacin serves as an attractant and feeding stimulant, as well as a defense against predators after ingestion (Gould and Massey 1984; Tallamy et al. 1998). Cucurbit species that produce lower levels of cucurbitacin are less attractive to the striped cucumber beetle and, as such, less susceptible to feeding damage. Watermelon is resistant to bacterial wilt disease, while cucumbers are highly susceptible. Growers may consider planting disease-resistant cucurbit crops, less attractive cucurbit crops, or some combination thereof, to reduce yield losses. Cultivating disease-resistant crops also allows for greater tolerance of beetle feeding damage, reducing the need for synthetic insecticides (Hoffmann and Zitter 1994).

\section{Crop Rotations}

Since striped cucumber beetle populations overwinter near cucurbit fields from the previous year, spatial avoidance of local populations may be achieved by maximizing the distance between cucurbit fields in successive growing seasons. Natural or man-made landscape features, such as hedgerows or buildings, can serve as barriers between fields, acting to delay or reduce colonization of newly planted cucurbit fields (Boucher 2003).

\section{Trap Crops, Baits, and Attractants}

The striped cucumber beetle uses natural volatile compounds to locate suitable host plants, and cucurbit producers can use the same compounds against the beetles in their management efforts (Lewis et al. 1990). Trap crops, which may be comprised of a small number of highly attractive cucurbits (i.e., high cucurbitacin concentration) planted around the field perimeter, may lure beetle populations away from cultivated fields (Hahn 2005), particularly since fields are colonized from the outer margins first (Luna and Xue 2009). Insecticides may then be applied to trap crops, but kept out of the cultivated field (Cavanagh et al. 2009). Attracticidal baits, using a combination of cucurbitacin attractant and a small quantity of insecticide, have been shown to lure and kill striped cucumber beetles, while 
again reducing the need for a foliar insecticide application (Boucher 2003).

\section{Transplanting Seedlings Rather than Direct Seeding}

Temporal avoidance of peak striped cucumber beetle populations may be achieved by avoiding direct seeding of cucurbits in favor of planting seedlings. Since seedlings early in the season are most vulnerable to striped cucumber beetle attack, the duration of this susceptible period may be shortened by transplanting seedlings into the field rather than direct seeding the crop (Yao et al. 1996; Hoffmann et al. 2002).

\section{Intercropping and Physical Barriers}

Intercropping cucumbers with corn and broccoli was shown to significantly reduce striped cucumber beetle incidence (Bach 1980), and radish, nasturtium, tansy, buckwheat, cowpea, and sweet clover have been suggested as intercrops as well (Cline et al. 2008). Synthetic physical barriers, such as floating row covers, can also protect plants against striped cucumber beetle attack, but must be removed to allow for pollination of blossoms (Snyder 2015).

\section{Natural Mulches}

Natural materials used as mulches can enhance soil nutrient levels, act as physical barriers, and support beneficial insect communities. The physical complexity of straw mulch can slow the movement of striped cucumber beetles from plant to plant (Olkowski 2000) and provide habitat for natural enemies (Snyder and Wise 2001; Williams and Wise 2003). Also, the organic nutrients resulting from the residual breakdown of the straw attracts a diverse community of decomposers, supporting the establishment of predators and other beneficial insects in cucurbit fields (Halaj and Wise 2002). Other organic amendments commonly employed as mulches, such as food wastes and vermicompost, can contribute to reduced striped cucumber beetle abundance. The slow release of nutrients from organic mulches results in a slower buildup of nitrogen in the foliage, compared to synthetic inputs, and decreases the crop's attractiveness to colonizing beetles (Yardim et al. 2006).

\section{Organic Insecticides}

Organically-approved botanical insecticides are generally reported to be weak control options for the striped cucumber beetle (Snyder 2015), having been shown to be less effective than intercropping or reflective plastic mulch (Cline et al. 2008). A kaolin clay feeding deterrent has shown some efficacy, although results have been inconsistent (Hazzard et al. 2002).

\section{Conventional Insecticides}

Over 100 synthetic insecticide products are and/or have been registered for use against the striped cucumber beetle (Dill and Kirby 2016). Soil drenches are favored by growers during the early seedling stage and foliar treatments are applied later in the season as needed (Wilson et al. 2014). The use of broad spectrum insecticides should be limited, to minimize resistance-development, and used within a broader integrated pest management program. Striped cucumber beetle management with conventional insecticides should aim to minimize the non-target effects on the honey bee (Apis mellifera L.) and other important beneficial arthropods by incorporating a variety of management tactics.

\section{Selected References}

Bach CE. 1980. Effects of plant density and diversity on the population dynamics of a specialist herbivore, the striped cucumber beetle, Acalymma vittata (Fab). Ecology 61: 1515-1530.

Bessin R. 2010. Cucumber beetles. ENTFACT-311. College of Agriculture Food and Environment, University of Kentucky, Lexington, Kentucky. (Accessed 04/10/2018).

Boucher TJ. 2003. Striped cucumber beetles. UConn Cooperative Extension, Vernon, Connecticut. (Accessed 04/10/2018).

CABI 2018. Acalymma vittatum (striped cucumber beetle). (Accessed 03/29/2018).

Cavanagh A, Hazzard R, Adler LS, Boucher J. 2009. Using trap crops for control of Acalymma vittatum (Coleoptera: Chrysomelidae) reduces insecticide use in butternut squash. Journal of Economic Entomology 102: 1101-1107.

Choo HY, Koppenhofer AM, Kaya HK. 1996. Combination of two entomopathogenic nematode species for suppression of an insect pest. Journal of Economic Entomology 89: 97-103.

Cline GR, Sedlacek JD, Hillman SL, Parker SK, Silvernail AF. 2008. Organic management of cucumber beetles in watermelon and muskmelon production. Horttechnology 18: 436-444. 
Deheer CJ, Tallamy DW. 1991. Affinity of spotted cucumber beetle (Coleoptera: Chrysomelidae) larvae to cucurbitacins. Environmental Entomology 20: 1173-1175.

Dill JF, Kirby CA. 2016. Striped cucumber beetle. Pest Management Fact Sheet 5038. University of Maine. Maine, USA. (Accessed 04/10/2018).

Duval J. 1994. La chrysomele rayée du concombre. Ecological Agriculture Projects Agro-Bio 320. (Accessed 04/10/2018).

Eaton AT. 2016. Striped cucumber beetle. Pest fact sheet 20. University of New Hampshire Extension. (Accessed 04/10/2018).

Ellers-Kirk CD, Fleischer SJ, Snyder RH, Lynch JP. 2000. Potential of entomopathogenic nematodes for biological control of Acalymma vittatum (Coleoptera: Chrysomelidae) in cucumbers grown in conventional and organic soil management systems. Journal of Economic Entomology 93: 605-612.

Ellers-Kirk C, Fleischer SJ. 2006. Development and life table of Acalymma vittatum (Coleoptera: Chrysomelidae), a vector of Erwinia tracheiphila in cucurbits. Environmental Entomology 35: 875-880.

Gould F, Massey A. 1984. Cucurbitacins and predation of the spotted cucumber beetle, Diabrotica undecimpunctata howardi. Entomologia Experimentalis et Applicata 36: 273-278.

Hahn J. 2005. Striped cucumber beetles. University of Minnesota Extension. (Accessed 04/10/2018).

Halaj J, Wise DH. 2002. Impact of a detrital subsidy on trophic cascades in a terrestrial grazing food web. Ecology 83: 3141-3151.

Hazzard RV, Wick R, Howell J, Andenmatten T. 2002. Evaluation of management strategies for striped cucumber beetle and bacterial wilt in pumpkin, 2001 and 2002. University Massachusetts Extension Vegetable Program. $11 \mathrm{p}$.

Hoffman MP, Zitter TA. 1994. Cucumber beetles, corn rootworms, and bacterial wilt in cucurbits. Vegetable MD Online. Cornell Cooperative Extension. (Accessed 04/10/2018).
Hoffmann MP, Ayyappath R, Kirkwyland JJ. 2000. Yield response of pumpkin and winter squash to simulated cucumber beetle (Coleoptera: Chrysomelidae) feeding injury. Journal of Economic Entomology 93: 136-140.

Hoffmann MP, Ayyappath R, Gardner J. 2002. Effect of striped cucumber beetle (Coleoptera: Chrysomelidae) foliar feeding on winter squash injury and yield. Journal of Entomological Science 37: 236-243.

Houser JF, Balduf WV. 1925. The striped cucumber beetle. Bulletin of the Ohio Agricultural Experiment Station 388: 239-364.

Hummel RL, Walgenbach JF, Barbercheck ME, Kennedy GG, Hoyt GD, Arrellano C. 2002. Effects of production practices on soil-borne entomopathogens in western North Carolina vegetable systems. Environmental Entomology. 31: 84-91.

Isley D. 1927. The striped cucumber beetle. Arkansas Agricultural Experimental Station Bulletin 216.

Jarvis WR. 1994. Flétrissement bactérien, pp. 136-137. In C. Richard and G. Boivin [eds.]. Maladies et ravageurs des plantes légumiéres au Canada. Société canadienne de phytopathologie et Société d'entomologie du Canada, Ottawa. 590 p.

Legault G. 2007. Effect of kaolin on the striped cucumber beetle (Acalymma vittatum) and cucumber growth and development. Master's thesis. McGill University. Montreal, Quebec, Canada.

Lewis PA, Lampman RL, Metcalf RL. 1990. Kairomonal attractants for Acalymma vittatum (Coleoptera: Chrysomelidae). Environmental Entomology 19: 8-14.

Luna JM, Xue L. 2009. Aggregation behavior of Western spotted cucumber beetle (Coleoptera: Chrysomelidae) in vegetable cropping systems. Environmental Entomology 38: 809-814.

Macintyre JK. 2000. Biology and control of Acalymma vittatum (Fabricius), the striped cucumber beetle, in southwestern Ontario. Master's thesis. University of Guelph. Guelph, Ontario, Canada.

Munroe DD, Smith RF. 1980. A revision of the systematics of Acalymma sensu stricto Barber (Coleoptera: Chrysomelidae) from North America including Mexico. Memoirs of the Entomological Society of Canada 112: 1-91. 
Olkowski W. 2000. Mass trapping western spotted cucumber beetles. OFRF Information Bulletin No. 8 (Summer). Santa Cruz, CA: Organic Farming Research Foundation, pp. 17-22.

Radin AM. 1996. Bacterial wilt, pp. 36 In T. A. Zitter, D. L. Hopkins, and C. E. Thomas [eds.]. Compendium of Cucurbit Diseases. APS Press, St-Paul, MN. 87p.

Radin AM, Drummond FA. 1994. Patterns of initial colonization of cucurbits, reproductive activity and dispersion of striped cucumber beetle, Acalymma vittata (F.) (Coleoptera: Chrysomelidae). Journal of Agricultural Entomology 11: 115-123.

Reed DK, Reed GL, Creighton CS. 1986. Introduction of entomogenous nematodes into trickle irrigation systems to control striped cucumber beetle (Coleoptera: Chrysomelidae). Journal of Economic Entomology 79: 1330-1333.

Riley EG, Clark SM, Seeno TN. 2003. Catalog of the leaf beetles of America north of Mexico (Coleoptera: Megalopodidae, Orsodacnidae and Chrysomelidae, excluding Bruchinae). Coleopterists Society, Special Publication no. 1, 290 pp.

Smyth RR, Hoffmann MP. 2010. Seasonal incidence of two co-occurring adult parasitoids of Acalymma vittatum in New York State: Centistes (Syrrhizus) diabroticae and Celatoria setosa. Biocontrol 55: 219-228.

Snyder WE. 2015. Managing cucumber beetles in organic farming systems. Department of Entomology, Washington State University Pullman, WA. (Accessed 04/10/2018).

Snyder WE, Wise DH. 2001. Contrasting trophic cascades generated by a community of generalist predators. Ecology 82: $1571-1583$.

Tallamy DW, Whittington DP, Defurio F. 1998. Sequestered cucurbitacins and pathogenicity of Metarhizium anisopliae (Moniliales: Moniliaceae) on spotted cucumber beetle eggs and larvae (Coleoptera: Chrysomelidae). Environmental Entomology 27: 366-372.

Villeneuve C, Couture I. 2006. Bulletin d'information - Insecticides et fongicides homologués pour les cucurbitacées en 2006. Réseau d'avertissements phytosanitaires (RAP) Vol. $1.8 \mathrm{p}$.
Webb S. 2010. Insect Management for Cucurbits (Cucumber, Squash, Cantaloupe, and Watermelon). ENY-460. Gainesville: University of Florida Institute of Food and Agricultural Sciences.

Whitaker JO. 1995. Food of the big brown bat Eptesicus fuscus from maternity colonies in Indiana and Illinois. American Midland Naturalist 134: 346-360.

Williams JL, Wise DH. 2003. Avoidance of wolf spiders (Araneae: Lycosidae) by striped cucumber beetles (Coleoptera: Chrysomelidae): Laboratory and field studies. Environmental Entomology 32: 633-640.

Wilson MJ, Day E, Kuhar TP. 2014. Striped cucumber beetle. Virginia Polytechnic Institute and State University. Document number ENTO-61NP. (Accessed 04/10/2018).

Yao C, Zehndet G, Bauske E, Kloepper J. 1996. Relationship between cucumber beetle (Coleoptera: Chrysomelidae) density and incidence of bacterial wilt of cucurbits. Journal of Economic Entomology 89: 510-514.

Yardim EN, Arancon NQ, Edwards CA, Oliver TJ, Byrne RJ. 2006. Suppression of tomato hornworm (Manduca quinquemaculata) and cucumber beetles (Acalymma vittatum and Diabotrica undecimpunctata) populations and damage by vermicomposts. Pedobiologia 50: 23-29. 